\title{
PENGARUH LITERASI KEUANGAN DALAM MODEL PREDIKSI PILIHAN KARIR MAHASISWA PERGURUAN TINGGI DI KOTA PONTIANAK
}

\author{
Arianto ${ }^{1)}$, Zulfikar $^{2)}$, \& Tashadi Tarmizi ${ }^{3)}$ \\ 1, 2, 3 Jurusan Akuntansi, Politeknik Negeri Pontianak \\ 1 email: om_too@yahoo.com \\ 2 email: joel_acc@yahoo.com \\ ${ }^{3}$ email: tashaditarmizi@yahoo.co.id
}

\begin{abstract}
This research begins with the assumption that financial decision making is based on an understanding of financial literacy. And indicators of independent career decisions (selfemployment) are used to explain and prove the truth of these assumptions. This study models the predictions of student career choices by relating it to the financial literacy amongs higher education students in Pontianak. The descriptive quantitative method was chosen as the Research method. The survey was administered over a three-week period during the mid of 2018. The survey were administered in ways of randomly asked students to fill a survey out online A total of 200 surveys were completed, but only 174 responses were analysed. The results of the response are processed mathematically in predictive modeling (probit-logit model) of student career choices from their relationship with financial literacy and other additional variables. The probit-logit analysis of this model was carried out with the help of statistical software, namely SPSS. The output of the research model found that knowledge of cash flow (finlit1), entrepreneurial competency variables (entshp) and risk taking confidence variables (confid) had statistical significance $(<0.05)$ as a variable that influenced the decision for self-employment. While the independent variables are demographic variables, none of them have statistical significance to be said to influence career decisions to become self-employed. Similarly had also been found in others independent variables, which were "knowledge of asset types" (finlit2), "knowledge of insurance" (finlit3), "knowledge of investment types" (finlit4), and "knowledge of financial transactions" (finlit5).
\end{abstract}

Keywords: financial literacy and entrepreneurship.

\section{PENDAHULUAN}

Pendidikan tinggi dirasakan memiliki peningkatan derajat kepentingan sebagai kesempatan dalam meningkatkan daya saing (competitiveness) individu maupun nasional (Istiariani, 2020). Indonesia berdasarkan peringkat daya saing global yang dikeluarkan Forum Ekonomi Dunia (WEF, 2016) berada pada peringkat 37 dengan salah satu kontribusi terbesar terhadap peringkat tersebut disumbangkan oleh pilar pendidikan tinggi. Hal ini tentunya menambah tekanan bagi pendidikan tinggi dari para stakeholder untuk mampu menjawab tantangan penyediaan tenaga kerja berkualitas dan terampil ditahun 2030 yang mencapai 113 juta jiwa.

Dalam satu dekade terakhir, terdapat fenomena dalam pendidikan tinggi untuk menumbuhkan komunitas wirausaha yang disertai dengan pendanaan yang signifikan 
baik oleh pemerintah dan organisasi swasta. Inisiatif memperkenalkan wirausaha sebagai opsi karir bagi lulusan perguruan tinggi ini hendaknya disertai dengan pemahaman yang lebih jelas atas kebutuhan umum seorang entrepreneur dalam bersikap, bertindak dan mengambil keputusan terkait aspek entrepreneurial.

Seorang entrepreneur adalah individu yang percaya diri untuk berkarir secara mandiri dan secara sadar mampu untuk melihat dan menghadapi tantangan dan resiko dari sebuah aktifitas usaha (bisnis). Sebaliknya jika kondisi tersebut tidak terpenuhi dalam diri seorang individu, maka tidak mengherankan jika alternatif untuk menjadi seorang karyawan yang akan menjadi pilihan dari karirnya. Namun, pilihan karir sebagai seorang entrepreneur tidak semata muncul dari seorang yang memiliki ide bisnis, keberanian mengambil resiko serta pengambilan keputusan yang tepat. Terdapat asumsi yang menyatakan bahwa seseorang dengan pengetahuan keuangan yang baik lebih memiliki kemungkinan untuk memilih karir mandiri (entrepreneur) dan bertahan dalam usaha mandirinya tersebut) (Cumurovi'c and Hylly, 2017).

Pengetahuan keuangan lebih dikenal sebagai literasi keuangan dianggap sebagai dasar dari pembangunan ekonomi dan keberlanjutan (Bryant dalam Krechovská, 2015). Dalam pendapatnya, literasi kuangan adalah sesuatu yang esensial dalam menciptakan kehidupan yang sukses dan mandiri, memdorong kualitas hidup dan mempertahankan keberlangsungannya. Sementara itu, Rahmandoust et al. (2011) sebagaimana dikutip Krechovská, (2015) mengarisbawahi pentingnya literasi keuangan dalam kesuksesan seorang wirausawan dan kontribusinya dalam membangun ekonomi masyarakat yang berkelanjutan.
Individu dengan literasi keuangan dipahami sebagai mereka dengan pengetahuan atas konsep-konsep keuangan serta produk keuangan yang tersedia, sehingga dianggap akan lebih mampu dalam mewujudkan ide bisnis serta mendanai usaha mereka tersebut. Mereka dengan literasi keuangan yang baik akan lebih mampu mengidentifikasi alternatif pembiayaan yang tersedia serta mampu memahami persyaratan dan perjanjian pembiayaan yang menyertainya. Kemampuan dalam mengidentifikasi alternatif pembiayaan yang tersedia serta mampu memahami persyaratan dan perjanjian pembiayaan telah diungkap sebagai salah satu faktor rendahnya akses modal pagi UMKM di Indonesia (Suara Karya, 2012).

Entrepreneur dengan pengetahuan yang memadai dianggap lebih mampu mengelola transaksi bisnisnya (Nunoo et al dalam Njoroge, 2012). . Banyak survey yang hasilnya menunjukan bahwa usaha (kategori kecil-menengah) yang dijalankan oleh seorang entrepreneur dengan pengetahuan keuangan yang memadai memiliki kemungkinan mencatatkan tingkat kinerja lebih baik dibanding kategori sebaliknya (Njoroge, 2012).

Literasi keuangan pada entrepreneur digambarkan dengan; 1) keberadaan keahlian keuangan dan manajemen keuangan; 2) keberadaan pengetahuan atas siklus pendanaan usaha dan penyedia jasa keuangan serta prosedur untuk mendapatkannya; 3) memahami keberadaan resiko keuangan dan kesediaan untuk mempelajarinya; 4) memahami aspek hukum, regulasi dan perpajakan; 5) memahami situasi dan konsekuensi hokum terkait usaha dan pihak-pihak yang dapat dimintai kerjasamanya dalam menghadapi situasi yang tidak diharapkan (fatoki, 2014).

Pertimbangan keuangan dalam bentuk pengetahuan keuangan yang memadai hendaknya menjadi sesuatu yang dimiliki 
bagi mahasiswa dalam memutuskan karir yang akan dipilih, apalagi jika berkeinginan memulai usaha (calon wirausaha). Mereka yang memutuskan untuk berwirausaha sebagai pilihan karirnya hendaknya tidak memandang resiko menjalankan bisnis hanya ditentukan atas seberapa baiknya membangun dan merealisasikan ide bisnis namun juga harus pempertimbangkan faktor keputusan keuangan yang diambil. Sebagai kaum milenial, mahasiswa hendaknya mendasari keputusan karir wirausahanya dengan pengetahuan pengelolaan usaha secara efisien, dan peduli atas tekanan ini dari pihak eksternal, terutama terkait keputusan mengenai Uang (Njoroge, 2012).

Fenomena atas cukup banyaknya keahlian berbisnis yang mendapat porsi dalam program pendidikan dan pelatihan wirausaha di perguruan tinggi, tidak dipungkiri telah mendorong tumbuhnya minat memilih wirausahawan sebagai pilihan karir bagi mahasiswa. Di lain pihak kemampuan dan pengetahuan keuangan masih dirasakan belum mendapatkan perhatian yang proporsional. Berwirausaha sebagai wujud dari inisiatif dan keputusan investasi hendaknya dibangun dengan melibatkan pertimbangan keuangan yang memadai, bukan hanya atas motivasi untuk mewujudkan sebuah usaha baru dan memiliki nilai jual semata (Avlijaš et all, 2014). Keberadaan atribut personal literasi keuangan diyakini berkontribusi ikut menentukan pilihan karir seseorang sebagai entrepreneur, sehingga sebuah program kewirausahaan di PT dapat menjadikan pengukuran atribut ini sebagai dasar pengetahuan dalam mengoptimalkan pelaksanaan program.

Program Mahasiswa Wirausaha (PMW) yang salah satunya di jalankan oleh Politeknik Negeri Pontianak dapat dijadikan sebagai gambaran pelaksanaan program pengembangan kewirausahaan yang mendapat dukungan secara terstruktur dan sistematis dalam hal pengelolaan dan pembiayaan. Namun, implementasi program tersebut masih mengindikasikan ruang pengembangan dan perbaikan yang perlu mendapatkan perhatian.

Evaluasi atas implementasi program telah mencatatkan tingkat pengembalian pinjaman modal kerja yang tidak signifikan. Pinjaman modal kerja untuk memulai usaha bagi mahasiswa peserta PMW tidak dapat dibayarkan kembali oleh para peserta tersebut. Singkatnya, hal ini mengindikasikan kesulitan keuangan yang dihadapi oleh mahasiswa atas usaha yang dijalankannya. Penyebab umum dari hal tersebut dapat dikarenakan jumlah pinjaman yang melebih kebutuhan usaha sebenarnya (overbudget) dan atau pengeluaran yang melebihi pendapatan usaha (unmatch budget). Jelaslah bahwa pengelolaan keuangan menjadi masalah yang berkontribusi atas fenomena ini. Yang mana literasi keuangan diyakini penulis memiliki hubungan atas kompetensi dan keputusan pengelolaan keuangan seorang entrepreneur.

Mahasiswa dan generasi muda yang secara umum menjadi target dari programprogram pendidikan dan pengembangan sumberdaya manusia hendaknya dibekali dengan berbagai kompetensi penting dalam menunjang karirnya. Pilihan karir; mulai dari membuat dan menjalankan usaha, sebagai karyawan maupun ketika memutuskan memulai untuk berkeluarga akan memberikan implikasi pada aktifitas ekonomi dimana pun mereka berada. Pendidikan keilmuan, keahlian serta kewirausahaan yang diyakini sebagai kompetensi dalam meningkatkan daya saing generasi muda hendaknya disertai pengetahuan keuangan dengan porsi yang cukup, terutama bagi program-program kewirausahaan di tingkat perguruan tinggi (Goetz et al. Krechovská, 2015).

Penelitian ini dimulai dengan asumsi bahwa pengambilan keputusan keuangan 
didasari oleh pemahaman atas literasi keuangan. Dan indikator keputusan karir mandiri (self-employment) digunakan untuk menjelaskan dan membuktikan kebenaran asumsi tersebut. Penelitian ini memodelkan prediksi pilihan karir mahasiswa dengan merelasikannya terhadap literasi keuangan yang dilakukan pada mahasiswa di Kota Pontianak. Dengan memahami relasi antara literasi keuangan dan kecendrungan atas karir yang dipilih, diharapkan nantinya dapat dirumuskan penyelenggaraan program yang lebih tepat sebagai penunjang pilihan karir bagi mahasiswa nantinya.

\section{KAJIAN LITERATUR}

\subsection{PENGETAHUAN KEUANGAN (FINANCIAL LITERACY)}

Pengetahuan keuangan (financial literacy) telah banyak mendapat perhatian oleh banyak pihak yang berkepentingan dalam program pemberdayaan kewirausahaan sebagai sesuatu yang penting.

Namun yang tidak kalah pentingnya adalah adanya kesepahaman atas terminologi Pengetahuan keuangan (financial literacy). Terminologi Pengetahuan keuangan (financial literacy) diungkapkan sebagai kombinasi dari konsep kepekaan dan pengetahuan keuangan; dalam hal informasi produk keuangan dan institusi keuangan, konsep keuangan (bunga, inflasi) dan kemampuan pengelolaan dan perencanaan keuangan (Xu dan Zia dalam Avlijaš et all, 2014). Keberadaan kombinasi konsep tersebut sering dijumpai memberikan implikasi yang berbeda pada berbagai Negara dengan kategori tingkat pendapatan yang berbeda.

Pada negara maju, dimana jasa keuangan telah menjadi industri, literasi keuangan diharapkan sebagai alat untuk melindungi pengguna jasa keuangan, dimana dengan pengetahuan keuangan yang cukup, pengguna jasa keuangan dapat lebih memahami produk-produk jasa keuangan dan diharapkan dapat mengambil keputusan dengan baik. Pada negara dengan tingkat serapan tenaga kerja yang terbatas dimana berwirausaha menjadi suatu alternatif penggerak ekonomi, literasi keuangan lebih dipandang sebagai praktik manajemen keuangan untuk menunjang keputusan memulai dan menjalankan usaha (Avlijaš et all, 2014).

Sering kali literasi keuangan dikaitkan dengan keputusan berwirausaha, namun dapat dikatakan bahwa aspek kepribadian dan karakter dari seseorang yang memiliki literasi keuangan juga yang baik juga ditemukan dalam bidang pekerjaan mandiri (self-employment) yang lain, dan diyakini bahwa aspek ini secara umum berkontribusi dalam keputusan pilihan karir seseorang (Cumurovi'c and Hylly, 2017).

Literasi keuangan memungkinkan seseorang untuk memiliki pengetahuan atas kendali resiko keuangan (Caliendo et al dalam Cumurovi'c dan Hylly, 2017). Kendali atas resiko keuangan ini yang diyakini dapat meningkatkan kemungkinan individu untuk memutuskan mandiri dalam bekerja yang umumnya dikenal istilah entrepreneur.

Seorang entrepreneur membutuhkan literasi keuangan dalam mengakses pinjaman dan jasa lembaga keuangan lainnya baik untuk kebutuhan hidup dan kebutuhan usaha yang akan dimulai. Industri keuangan yang berkembang dan diikuti dengan tumbuhnya persaingan antar institusi keuangan, menjadikan individu sangat rentan dengan tawaran dan opsi-opsi kemudahan bertransaksi keuangan. Kemudahan memperoleh pinjaman, penggunaan kartu kredit dan berbagai opsi transaksi keuangan sering dianggap berkorelasi langsung dengan pola belanja dan konsumsi yang tidak terkendali dan berujung pada kondisi keuangan pribadi dan atau keluarga yang tidak sehat (Marcolin and Abraham, 2006; Beal and Delpachitra, 2003; dalam Krechovská, 2015). Kemudahan yang 
sekaligus ancaman tersebut, diyakini dapat ditangkal dan dikendalikan dengan pengetahuan dasar keuangan yang memadai (literasi keuangan).

Literasi keuangan secara umum dapat diartikan sebagai tingkatan pengetahuan dan kepekaan individu untuk mengolah informasi ekonomi dan mengambil keputusan terkait perilaku keuangan. Istilah literasi keuangan (financial literacy) banyak dihubungkan dengan survey yang dilakukan oleh institusi the jump start terhadap siswa-siswa sekolah menengah atas pada tahun 1997. Pada penelitian tersebut literasi keuangan didefinisikan sebagai "the ability to use knowledge and skills to manage one's financial resources effectively for lifetime financial security" (Mandell dalam Krechovská, 2015).

Literatur-literatur yang mengungkap literasi keuangan pada periode awal kemunculannya juga sepakat untuk mendefenisikannya sebagai kemampuan dan atau kapasitas individu, baik sebagai konsumen maupun sebagai pemilik usaha untuk memahami dan mempertimbangkan informasi keuangan dan produk keuangan dalam memutuskan, menggunakan dan mengelola uang secara efektif (Krechovská, 2015).

Adapun literasi keuangan yang sering ditemukan dalam berbagai literatur secara umum diarahkan pada tiga konsep keuangan yang fundamental, yakni: perhitungan bunga (nilai waktu uang), inflasi (perubahan tingkat harga) dan diversifikasi resiko.

Seseorang dengan literasi keuangan yang memadai akan terbiasa dengan topik-topik pembicaraan seputar keuangan dan mekanisme harga, selain itu juga akan mampu mengelola pendapatan dan belanja pribadi dan keluarga dengan bijak. Pengetahuan ini juga diindikasikan atas keberadalan alokasi aset dan manajemen hutang yang menggambarkan pertimbangan atas perubahan kondisi keuangan dimasa mendatang (Krechovská, 2015). Dapat dikatakan bahwa literasi keuangan ditujukan pada upaya mengarahkan individu untuk membuat penilaian yang tepat, pengambilan keputusan yang efektif dan bertindak secara relevan dengan memperhitungkan konsekuensi keuangan. Cumurovi'c dan Hylly (2017) secara empiris mengemukakan bahwa terdapat relasi positif antara literasi keuangan (financial literacy) dan karir mandiri (self-employment). Penelitian tersebut menunjukan bahwa individu dengan tingkat literasi yang lebih rendah lebih mingkin untuk bekerja sebagai karyawan disbanding memutuskan untuk berkarir mandiri/wiraswasta (self-employment).

Anggapan bahwa literasi keuangan dapat mendorong tingkat kemungkinan dari keputusan karir mandiri (self employment) ditunjang oleh antribut pengetahuan literasi keuangan yang memberikan kontribusi terhadap penyerapan dan pemprosesan informasi oleh individu yang memilikinya. Sebagai hasilnya, seseorang dengan literasi keuangan dapat memanfaatkan informasi yang didapatnya untuk lebih percaya diri dalam memperhitungkan resiko (risk assessments), melihat lebih baik kesempatan mewujudkan ide usaha, sehingga lebih berani memutuskan untuk bekerja secara mandiri (Cumurovi'c dan Hylly, 2017).

Lebih lanjut, entrepreneur sebagai wujud paling nyata dari karir mandiri ketika dihubungkan dengan literasi keuangan, mengindikasikan adanya hubungan dengan aktifitas akuntansi dasar (pencatatan keuangan). Dimana unit usaha dengan literasi keuangan yang terbatas, akan menjadi terbatas pula dalam mendapatkan akses atas jasa keuangan formal, yang salah satunya mensyaratkan keberadaan sistem pencatatan keuangan yang memadai. Literasi keuangan juga dianggap memiliki hubungan dengan kepatuhan dalam memenuhi aspek legal/formal sebuah aktifitas usaha dalam hal 
operasi dan organisasi (Xu dan Zia dalam Avlijaš et al, 2014).

\subsection{KOMPETENSI KEUANGAN DALAM PILIHAN KARIR MANDIRI}

Pilihan karir seseorang tersebar atas berbagai macam opsi, mulai dari menjadi seorang buruh, karyawan, pengawai negeri, petani, pekerja professional (bidang hukum, keuangan, kesehatan, kesenian, dll), pengusaha dan pedagang maupun seorang freelancer.

Opsi-opsi tersebut dapat dikelompokkan menjadi kelompok pekerjaan dependen/pekerja (employee) dan kelompok pekerjaan independen /mandiri (selfemployment). Kelompok pekerjaan mandiri secara luas meliputi jenis pekerjaan sebagai petani, pekerja professional (bidang hukum, keuangan, kesehatan, kesenian, dll), pengusaha dan pedagang maupun seorang freelancer. Namun kelompok pekerjaan yang paling sering diasosiasikan dengan karir mandiri adalah sebagai wirausaha (entrepreneur).

Berbagai literatur mengungkapkan bahwa keputusan memilih pekerjaan mandiri dikontribusikan oleh tingkat kesiapan dalam mengambil resiko. Sikap yang mampu menilai resiko menjadi penentu dalam mengarahkan potensi karir yang akan diambil (Cumurovi'c dan Hylly, 2017). Seorang dengan pilihan karir mandiri, diyakini akan menunjukan indikasi yang signifikan terkait kompromi atas resiko dan beberapa karakter personal yang spesifik, seperti terbuka atas hal baru, optimis dan percaya diri (Dohmen et al. dalam Cumurovi'c dan Hylly, 2017).

Perbedaan antara pribadi sebagai pekerja dengan seorang yang bekerja mandiri secara lebih khusus terdapat dari beberapa karakteristik, Cumurovi'c dan Hylly (2017) mengungkapkan diantaranya adalah cara pandang dalam menjalani hidup, apakah hidup untuk saat ini atau merencanakan masa depan; cara pandang dalam mengerjakan sesuatu, apakah untuk hasil yang instan atau dampak dimasa yang akan datang; serta terkait reaksi yang diberikan, apakah bersifat implulsif dan cepat, atau cenderung mempertimbangkan dan penuh pengamatan.

Seseorang pekerja mandiri dari beberapa penelitian terdahulu lebih digambarkan sebagai seseorang yang secara signifikan lebih berani mengambil resiko, berfikiran jangka panjang dan cenderung mempertimbangkan dan penuh pengamatan sebelum mengambil keputusan keberadaan resiko dan implikasi serta antisipasi pada berbagai tingkatan sesuai dengan toleransi yang diberikan atas hasil yang diharapkan dimasa yang akan datang dapat dimenuhi melalui pengetahuan keuangan /literasi keuangan.

Pengetahuan keuangan (literasi keuangan) mengakumulasi berbagai kompetensi keuangan. Investment Solutions Northland (2015) menampilkan rangkaian berbagai pengetahuan, keahlian dan informasi yang dibutuhkan dalam kehidupan ekonomi modern. Rangkaian pengetahuan keuangan tersebut dibagi dalam tiga kelompok, yakni pengetahuan keuangan sehari-hari, pengetahuan keuangan tidak rutin, dan pengetahuan keuangan bagi spesialis (gambar 2.1).

\section{Gambar 2.1 Piramida literasi keuangan}

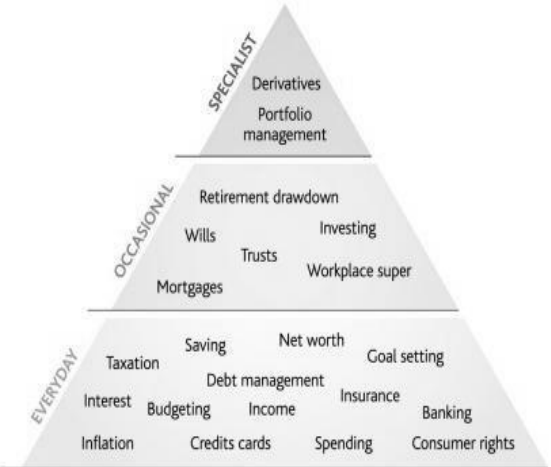

Sumber: Investment Solutions Northland (2015)

Fokus lain atas pengetahuan keuangan dikemukakan oleh literatur mengelompokannya atas tiga komponen 
dasar pengelolaan keuangan pribadi dan usaha, terdiri atas; 1) kompetensi yang cukup dalam mengelola uang dalam bentuk tunainontunai dan transaksi-transaksi terkait (rekening tabungan, metode pembayaran) yang dikenal dengan istilah "literasi uang"; 2) kompetensi yang cukup untuk memahami mekanisme harga, termasuk inflasi, nilai waktu-uang, perhitungan bunga, tingkat bunga serta biaya-biaya yang terkait transaksi keuangan, yang dikenal dengan istilah "literasi harga"; 3) kompetensi yang cukup dalam menyiapkan rencana keuangan dan tujuan keuangan, dapat dalam bentuk anggaran pendapatan dan belanja, yang disertai dengan prinsip kehati-hatian dalam pandangan keuangan ("literasi anggaran"); 4) kompetensi khusus dalam memahami pasar produk dan jasa keuangan, mampu membandingkan dan memilih produk dan jasa keuangan yang bersesuaian dengan situasi tertentu (Krechovská, 2015).

Menjadi seorang entrepreneur saat ini tengah dipromosikan sebagai pilihan karir mandiri bagi individu. Pengetahuan resiko ini oleh Caliendo et al. (Njoroge, 2012) memberikan potensi keberlangsungan usaha yang lebih besar bagi jalannya bisnis seorang entrepreneur. Entrepreneur dengan pengetahuan yang memadai dianggap lebih mampu mengelola transaksi bisnisnya (Nunoo et al dalam Njoroge, 2012). Banyak survei yang hasilnya menunjukan bahwa usaha (kategori kecil-menengah) yang dijalankan oleh seorang entrepreneur dengan pengetahuan keuangan yang memadai memiliki kemungkinan mencatatkan tingkat kinerja lebih baik dibanding kategori sebaliknya (Njoroge, 2012).

Literasi keuangan pada entrepreneur digambarkan dengan; 1) keberadaan keahlian keuangan dan manajem keuangan; 2) keberadaan pengetahuan atas siklus pendanaan usaha dan penyedia jasa keuangan serta prosedur untuk mendapatkannya; 3) memahami keberadaan resiko keuangan dan kesediaan untuk mempelajarinya; 4) memahami aspek hukum, regulasi dan perpajakan; 5) memahami situasi dan konsekuensi hokum terkait usaha dan pihak-pihak yang dapat dimintai kerjasamanya dalam menghadapi situasi yang tidak diharapkan (fatoki, 2014).

\subsection{LITERASI KEUANGAN DAN KEPRILAKUAN INDIVIDU DENGAN KARIR MANDIRI}

Pilihan karir mandiri menjadikan seseorang individu harus bertanggung jawab secara langsung terhadap hasil, dimana keahlian dan kesungguhan pribadi sangat diutamakan serta sadar akan keberadaan resiko. Keberadaan sifat-sifat tersebut dikemukakan oleh McClelland (Njoroge, 2012) sebagai need for achievement (nAch) yang olehnya ditambahkan bahwa individu yang memiliki tingkat need for achievement (nAch) yang tinggi, memiliki kecendrungan untuk memilih entrepreneur sebagai pilihan pekerjaan.

Aktifitas seorang entrepreneur sebagai salah satu bentuk karir mandiri (self employment) akan selalu berhadapan dengan ketidakpastian. Sehingga banyak literatur yang mengungkap keberadaan aspek pengambilan resiko (Risk Taking) dalam diri seorang entrepreneur. Resiko yang paling utama disebutkan adalah ketidakpastian laba (Venkataraman, dalam Njoroge, 2012), meskipun banyak pula aspek lain yang dicatatkan sebagai bentuk ketidak pastian yang akan dihadapi oleh seorang entrepreneur (Liles dalam Njoroge, 2012).

Selain motivasi yang tinggi, seorang dengan pilihan karir mandiri seperti menjadi entrepreneur hendaknya mampu menjalankan kegiatan entrepreneurial-nya secara ekonomis atau dengan kata lain adanya pertimbangan yang cukup terkait penggunaan sumberdaya dan hasil yang didapat. Ukuran pertimbangan ini secara umum adalah nilai uang. 
Pentingnya prilaku ekonomis sebagai bagian dari karakteristik seorang entrepreneur, diyakini akan diikuti dengan upaya meningkatkan pemahaman atas konsep-konsep yang mendasari prilaku tersebut. Dengan kata lain dibutuhkan pengetahuan yang cukup agar seseorang dapat bertindak sesuai dengan yang seharusnya (Braunstein dan Welch dalam Njoroge, 2012).

Pertimbangan dan prilaku ekonomi umumnya dihubungkan dengan pendidikan keuangan yang memberikan secara khusus rangkaian pengetahuan, sikap dan keahlian dalam bidang keuangan. Topik-topik pembahasan yang diantaranya; manajemen keuangan, bank dan lembanga keuangan, manajemen arus kas, manajemen investasi dan perpajakan adalah topik umum yang dijumpai dalam kurikulum. Namun dalam penyampaiannya seringkali kurang dijumpai penekanan yang cukup atas prilaku dan pertimbangan praktis dari topik tersebut dalam kehidupan sehari-hari (Coussens 2006; McCormick 2009; Vitt et al. 2005 dalam Njoroge, 2012). Pengetahuan keuangan akan berpengaruh pada prilaku keuangan, ini diungkap Hilgert, Hogarth, dan Beverly dalam Njoroge (2012) dalam sebuah survei yang hasilnya memberikan indikasi mengenai pendapat tersebut.

Pengetahuan secara umum telah diyakini mampu meningkatkan kualitas entrepreneur, Carter dan Jones- Evans dalam Njoroge (2012) mengemukakan pengetahuan dasar seperti matematika akan mampu memberi peluang sebuah kegiatan entrepreneurial untuk bertahan apalagi jika didukung dengan pengetahuan keuangan yang cukup. Pendapat ini dikuatkan oleh Hartog et al. Njoroge (2012) yang menyatakan bahwa kemampuan matematika, kemampuan teknis dan sosial merupakan kemampuan yang penting bagi para entrepreneur, bahkan dinyatakan keseimbangan dari komposisi pengetahuan tersebut akan berpengaruh terhadap pendapatan seorang entrepreneur.

Bersamaan dengan itu, kelompok kompetensi yang dikenal sebagai "literasi Informasi"-yakni mampu dalam menemukan, menggunakan dan menilai informasi yang relevan; "literasi numeric"yakni mampu melakukan perhitungan matematis atas permasalahan keuangan; serta "literasi hukum"-yakni pengetahuan atas aspek hukum dan legalitas, hak dan tanggungjawab, diyakini memberikan dukungan atas kompetensi keuangan yang dimiliki oleh seorang entrepreneur untuk mampu berkinerja dengan baik (Krechovská, 2015).

Literasi keuangan diyakini berperan penting dalam kontekstual pribadi maupun sebuah aktifitas usaha. Secara pribadi, literasi keuangan akan berperan dalam pengambilan keputusan keuangan personal. Sedangkan dalam konteks kegiatan usaha, seorang entrepreneur hendaknya mampu menerapkan konsep literasi keuangannya kedalam kebutuhan entitas usaha yang ia jalankan.

Lusardi dan Mitchell (dalam fatoki, 2014) mengungkapkan hubungan antara literasi keuangan dengan prilaku ekonomi individu, terutama pada aspek keputusan memiliki simpanan dan keputusan konsumsi. Dimana dengan berdasarkan penelitian Modigliani dan Brumberg (1954), Lusardi dan Mitchell menyatakan bahwa pola konsumsi individu pada periode tertentu adalah gambaran dari hasil perencanaan atas upaya menjaga keseimbangan kebutuhan hidup individu, sementara pendapatan pada periode tersebut memberikan kontribusi atas perencanaan yang dibuat. Hal ini menguatkan anggapan bahwa literasi keuangan akan berdampak pada prilaku seseorang.

Keberadaan prilaku dengan latar belakang literasi keuangan terlihat dari keputusan individu dalam upaya menanggulangi dampak dari resiko keuangan yang mungkin terjadi, yakni dengan memiliki 
simpanan di bank, asset yang beragam serta memiliki asuransi (fatoki, 2014)

Prilaku yang mengarah pada keputusan keuangan yang lebih baik serta pengetahuan dan antisipasi atas resiko, cenderung ditemukan pada entrepreneur dengan literasi keuangan yang baik. Penelitian yang dilakukan oelh Bruhn dan Zia ditahun 2011 (fatoki, 2014) mendapatkan hasil bahwa entrepreneur dengan literasi keuangan mampu menunjukan kinerja usaha dan penjualan yang lebih baik. Sementara Andoh and Nunoo (dalam fatoki, 2014) mengungkapkan pemilik usaha dengan literasi keuangan yang cukup lebih mampu memanfaatkan jasa lembaga keuangan.

Aktifitas Entrepreneurial hendaknya tidak dilihat hanya sebagai upaya memanfaatkan kesempatan, namun dilihat sebagai pemberdayaan segenap potensi diri mulai dari pengetahuan dan keahlian yang dimiliki. Potensi tersebut adalah kumpulan pengetahuan dan keahlian yang telah dimiliki sebelumnya, maka beberapa literatur mengungkapkan adanya hubungan yang kuat antara aktifitas entrepreneurial dengan sediaan pengetahuan (stock of knowledge) (Zoltan et al dalam Njoroge, 2012). Penelitian ini nantinya akan secara khusus mengungkapkan keberadaan pengetahuan keuangan sebagai sediaan pengetahuan seorang calon entrepreneur. Penelitian ini juga akan memberikan pemahaman bahwa pengetahuan keuangan tersebut dapat ditemukan dalam diri calon entrepreneur dengan berbagai latar belakang pendidikan.

Penelitian ini nantinya akan coba mengungkap keberadaan relasi literasi keuangan dengan pilihan karir mahasiswa pada perguruan tinggi di Kota Pontianak. Dengan merujuk pada teori yang dikemukakan diatas, nantinya diharapkan mampu memberikan penjelasan tentang fenomena pilihan karir yang diyakini penulis memiliki relasi dengan keberadaan pengetahuan keuangan dalam diri seorang.

\section{METODE PENELITIAN}

Metode kuantitatif dipilih sebagai metode penelitian. Pendekatan penelitian kuantitatif mencakup pemaparan numerikal (data angka) dan manipulasi sistematis atas hasil observasi yang dengan tujuan menggambarkan dan menjelaskan fenomena yang diteliti (baraghani, 2007). Penelitian ini sebagaimana layaknya penelitian kuantitatif menempatkan variabel penelitian dan keterhubungan sebagai pusat dari ide penelitian (Neuwman dalam Baraghani, 2007).

Hasil penelitian ini nantinya akan disajikan secara deskriptif, atas temuantemuan yang didapat melalui pengumpulan responsi atas kuesioner dari para responden penelitian. Hasil responsi tersebut nantinya akan diolah secara matematis dan diharapkan akan mengungkapkan fakta-fakta yang dapat menjelaskan fenomena yang diteliti.

Teknik pengumpulan data sangatlah tergantung dengan permasalahan penelitian. Penelitian ini memberikan fokus pada kondisi faktual atas pengetahuan bawaan dan motevasi responden terkait aspek keuangan. Dengan demikian teknik survei dianggap cocok untuk dipilih sebagai teknik pengumpulan data (Yin, dalam Baraghani, 2007).

Penulis menggunakan rancangan penelitian survei untuk mendapatkan data yang merepresentasikan literasi keuangan pada mahasiswa. Konsep literasi keuangan yang diukur adalah mengenai: sumberdaya keuangan, pengetahuan likuiditas asset, pengelola resiko, rencana keuangan dan pilihan investasi. Survei juga dirancang agar dapat memgumpulkan data mengenai informasi demografi, dan tentunya keputusan atas karir yang dipilih (pekerjaan dependen/karyawan (employee) atau pekerjaan independen/mandiri (selfemployment)). Sebagai tambahan survei juga menanyakan tentang pernah tidaknya 
responden pendapat matakuliah kewirausahaan dan pertanyaan terkait tingkat kepercayaan diri yakni pertanyaan tentang seberapa yakin responden atas jawaban benar dari pertanyaan literasi keuangan.

Survei akan dilakukan pada periode semester ganjil 2018 selama enam minggu. Survei dilakukan dengan tiga cara. Cara pertama adalah survei secara acak terhadap mahasiswa dengan melibatkan mahasiwa lainnya sebagai tenaga survei untuk mendatangi koleganya di lokasi-lokasi yang potensial. Cara kedua adalah melalui survei di kelas terhadap mahasiswa bekerjasama dengan dosen. Dan cara ketiga dengan mengarahkan mahasiswa mengisi survei secara online memanfaatkan platform survei yang tersedia secara gratis (situs google form) dengan tautan google form yaitu https://goo.gl/forms/Uv3feiUlrHvQ2W3v1.

Data diambil dengan variabel dummy, yakni memberikan nilai 1 atau 0 atas respon jawaban dari setiap pertanyaan survei. Khusus untuk pertanyaan terkait literasi keuangan nilai 1 diberikan untuk jawaban benar dan 0 diberikan untuk jawaban yang salah.

Sebagai varibel dependen adalah pilihan

\begin{tabular}{|c|c|c|c|}
\hline $\begin{array}{l}\text { Bidang } \\
\text { Ilmu }\end{array}$ & Jumlah & $\begin{array}{l}\text { Persentase } \\
\text { Jumlah }\end{array}$ & Kumulatif \\
\hline $\begin{array}{l}\text { Sosial dan } \\
\text { bisnis }\end{array}$ & 51 & $29 \%$ & $29 \%$ \\
\hline Keteknikan & 38 & $22 \%$ & $51 \%$ \\
\hline Agrikultur & 3 & $2 \%$ & $53 \%$ \\
\hline Pendidikan & 16 & $9 \%$ & $62 \%$ \\
\hline Keagamaan & 6 & $3 \%$ & $65 \%$ \\
\hline Bidang lain & 60 & $35 \%$ & $100 \%$ \\
\hline Total & 174 & $100 \%$ & \\
\hline
\end{tabular}

karir yang diinterpretasikan dengan nilai 1 untuk pekerjaan mandiri (entrepreneur) dan 0 untuk karir sebagai karyawan. Variabel independen adalah demografi, bidang keilmuan, literasi keuangan, pengetahuan kewirausahaan dan kepercayaan diri.

Aspek demografi meliputi; jenis kelamin (=1 Perempuan; =0 laki-laki), asal daerah $(=1$ kota Pontianak; $=0$ luar kota Pontianak). Variabel Bidang kelimuan yakni $(=1$ sosial/bisnis; $=0$ non-sosial /non-bisnis). Tingkat literasi keuangan diukur berdasarkan jawaban yang benar dari kelompok pertanyaan terkait literasi keuangan (5 pertanyaan), dengan asumsi; semakin banyak jawaban benar semakin tinggi tingkat literasi keuangan, yang mungkin memiliki relasi dengan pilihan karir bekerja secara mandiri. Pengetahuan kewirausahaan (entrepreneurship) dilihat dari pernah tidaknya mendapatkan mata kuliah kewirausahaan atau pelatihan kewirausahaan (=1 pernah; $0=$ tidak pernah), karena tujuan dari pendidikan kewirausahaan adalah membekali mahasiswa untuk melihat entrepreneurial sebagai suatu pilihan karir. Variabel tingkat kepercayaan diri diukur dari seberapa yakinnya responden atas ketepatan jawaban pada kelompok pertanyaan terkait literasi keuangan. Untuk melakukan pemodelan prediksi pilihan karir mahasiswa dari relasinya dengan literasi keuangan, digunakan analisis probit-logit model. Dengan persamaan yang memuat variabel dependen dan independen ditentukan sebagai berikut:

$$
\begin{aligned}
& \operatorname{Pr}(\mathrm{y})=\mathrm{F}(\beta 0+\beta 1 \mathrm{x} 1+\beta 2 \times 2+\beta 3 \times 3+\beta 4 \\
& \mathrm{x} 4+\beta 5 \mathrm{x} 5+\beta 6 \mathrm{x} 6+\beta 7 \times 7+\mathrm{ui}) \\
& \mathrm{y} \quad=\text { pilihan karir } \\
& \mathrm{x} 1 \quad=\text { gender } \\
& \mathrm{x} 2 \quad=\text { asal daerah } \\
& \mathrm{x} 3 \quad=\text { bidang ilmu } \\
& \mathrm{x} 4 \quad=\text { literasi keuangan } \\
& \mathrm{x} 5 \quad=\text { pengetahuan kewirausahaan } \\
& \mathrm{x} 6 \quad=\text { kepercayaan diri }
\end{aligned}
$$

Metode analisis probit-logit model ini akan dilakukan dengan bantuan softwere statistik yakni SPSS.

\section{HASIL PENELITIAN}

Dengan tujuan memperkirakan efek literasi keuangan terhadap kemungkinan pemilihan karir sebagai seorangan pekerja 
mandiri (self-employed), penelitian ini akan menyampaikan penelaahaan beberapa hal yang dianggap memiliki kaitan dengan pertimbangan keputusan karir dari seseorang.

Pendekatan variabel digunakan untuk mendapatkan informasi terkait pertimbangan karir seseorang yang di wakili oleh responden penelitian. Variabel pertama adalah level pendidikan, penulis membagi berdasarkan tingkatan tahun pada pendidikan tinggi yang sedang atau telah diikuti. Variabel ini juga diperjelas dengan bidang ilmu yang ditekuni.

Khusus mengenai variabel literasi keuangan, pengukuran didasarkan pada jawaban benar yang didapat oleh responden. Tingkat kepercayaan diri diwakilkan dari pengukuran pribadi terhadap perkiraan jawaban benar.

Selanjutnya, penulis juga menambahkan pengukuran pribadi atas potensi kewirausahaan yang dimiliki. Pengukuran tersebut meliputi rasa optimis, kompetensi, keyakinan atas pilihan yang dibuat. Analisis yang digunakan adalah model Probit-logit, yang umum dipakai dalam

Tabel 4.1 menjelaskan pilihan atas dua alternatif yang dalam penelitian ini adalah pilihan berkarir sebagai dalam pekerjaan dependen/karyawan (employee) atau pekerjaan independen /mandiri (selfemployment).

\subsection{URAIAN DEMOGRAFI SAMPEL PENELITIAN}

Responden atas penelitian ini melibatkan 174 respondent yang merupakan mahasiswa dan alumni perguruan tinggi di Kota Pontianak. Penentuan jumlah responden penelitian ini hanya didasarkan pada pertimbangan waktu dan kesediaan responden untuk memberikan informasi terkait masalah yang akan diungkapkan sebagai ketertarikan penelitian.

Mengawali pembahasan, disajikan karakteristik responden berdasarkan status kemahasiswaan, bidang keilmuan yang ditempuh pada perguruan tinggi, sebaran gender dan sebaran daerah asal domisili responden.

Tabel 5.1 Profil responden : Status Kemahasiswaan

\begin{tabular}{|c|c|c|c|}
\hline $\begin{array}{c}\text { Status } \\
\text { Kemahasiswaan }\end{array}$ & Jumlah & $\begin{array}{c}\text { Persentase } \\
\text { Jumlah }\end{array}$ & Kumulatif \\
\hline Tahun pertama & 98 & $56 \%$ & $56 \%$ \\
\hline Tahun terakhir & 62 & $36 \%$ & $92 \%$ \\
\hline Alumni<3 tahun & 10 & $6 \%$ & $98 \%$ \\
\hline Alumni $>3$ tahun & 2 & $1 \%$ & $99 \%$ \\
\hline $\begin{array}{l}\text { Tidak menempuh } \\
\text { PT }\end{array}$ & 2 & $1 \%$ & $100 \%$ \\
\hline Total & 174 & $100 \%$ & \\
\hline
\end{tabular}

Tabel 5.2 Profil Responden : Bidang Keilmuan

\begin{tabular}{|l|r|r|r|}
\hline Bidang Ilmu & Jumlah & $\begin{array}{c}\text { Persentase } \\
\text { Jumlah }\end{array}$ & Kumulatif \\
\hline $\begin{array}{l}\text { Sosial dan } \\
\text { bisnis }\end{array}$ & 51 & $29 \%$ & $29 \%$ \\
\hline Keteknikan & 38 & $22 \%$ & $51 \%$ \\
\hline Agrikultur & 3 & $2 \%$ & $53 \%$ \\
\hline Pendidikan & 16 & $9 \%$ & $62 \%$ \\
\hline Keagamaan & 6 & $3 \%$ & $65 \%$ \\
\hline Bidang lain & 60 & $35 \%$ & $100 \%$ \\
\hline Total & 174 & $100 \%$ & \\
\hline Sumber: Data olahan (2019) \\
\hline
\end{tabular}

Tabel 5.3 Profil Responden : Gender

\begin{tabular}{|c|c|c|c|}
\hline Gender & Jumlah & $\%$ & $\underset{\%}{\text { kumulatif }}$ \\
\hline Perempuan & 80 & $46 \%$ & $46 \%$ \\
\hline Laki-laki & 94 & $54 \%$ & $100 \%$ \\
\hline Total & 40 & & \\
\hline \multicolumn{4}{|c|}{ Sumber: Data olahan (2019) } \\
\hline
\end{tabular}

Tabel 5.4 Profil Responden : Asal Domisili

\begin{tabular}{|l|r|r|r|}
\hline \multicolumn{1}{|c|}{$\begin{array}{c}\text { Asal } \\
\text { Domisili }\end{array}$} & Jumlah & $\begin{array}{c}\text { Persentase } \\
\text { Jumlah }\end{array}$ & Kumulatif \\
\hline $\begin{array}{l}\text { Ibu kota } \\
\text { Provinsi }\end{array}$ & 71 & $41 \%$ & $41 \%$ \\
\hline $\begin{array}{l}\text { Ibu kota } \\
\text { kabupaten } \\
\text { /kota }\end{array}$ & 54 & $31 \%$ & $72 \%$ \\
\hline
\end{tabular}

Pengaruh Literasi Keuangan dalam Model Prediksi Pilihan Karir Mahasiswa Perguruan Tinggi di Kota Pontianak 


\begin{tabular}{|l|r|r|r|}
\hline Kecamatan & 25 & $15 \%$ & $87 \%$ \\
\hline $\begin{array}{l}\text { Kelurahan/ } \\
\text { desa }\end{array}$ & 24 & $13 \%$ & $100 \%$ \\
\hline Total & 174 & $100 \%$ & \\
\hline Sumber: Data olahan (2019) \\
\hline
\end{tabular}

Tabel 5.5 Chi-Square Tests

\begin{tabular}{|l|r|r|r|}
\hline \multirow{2}{*}{ Variabel } & \multicolumn{3}{|c|}{ Likelihood Ratio } \\
\cline { 2 - 4 } & \multicolumn{1}{|c|}{ Value } & \multicolumn{1}{c|}{ df } & $\begin{array}{c}\text { Asymp. } \\
\text { Sig. (2-sided) }\end{array}$ \\
\hline Gender & .417 & 1 & .518 \\
\hline Origin & 1.718 & 4 & .787 \\
\hline Program & 3.563 & 5 & .614 \\
\hline Eduyear & 3.675 & 4 & .452 \\
\hline Finlit1 & 1.817 & 1 & .178 \\
\hline Finlit2 & .487 & 1 & .485 \\
\hline Finlit3 & .012 & 1 & .913 \\
\hline Finlit4 & .002 & 1 & .968 \\
\hline Finlit5 & .746 & 1 & .388 \\
\hline Eship & 21.625 & 12 & .042 \\
\hline confdn & 1.354 & 1 & .245 \\
\hline Sumber: Data Olahan & \\
\hline
\end{tabular}

\subsection{URAIAN ANALISIS PROBIT- LOGIT}

Model Probit - logit memberikan ruang melakukan analisa atas dua alternatif pilihan karir mahasiswa dan lulusan Perguruan tinggi di kota Pontianak yang diwakili oleh intepretasi Binary yakni '0 jika memilih menjadi karyawan (employee) dan '1 jika memilin bekerja mandiri (self employed). Analisa ini melibatkan variabel independen sebagai mana disebutkan sebelumnya yakni variabel demografi dan variabel prilaku kognitif yakni literasi keuangan dan potensi kewirausahaan.

Pengujian pertama dilakukan untuk menjawab pertanyaan apakah terdapat hubungan yang signifikan antara variabel dependen (Pilihan karir) dengan variabelvariabel bebas yang dilibatkan dalam model prediksi yang diteliti. Analisis dikakukan melalui intepretasi output dari tabel Pearson Chi-Square Contingency.

Dengan menggunakan tingkat signifikansi 0.05 maka diperoleh kesimpulan bahwa secara parsial hanya variabel kompetensi Kewirausahaan (eship) yang memenuhi tingkat signifikan yang dipersyaratkan. Dengan demikian diduga sementara hanya satu variabel tersebut yang mampu memberikan prediksi atas model pilihan karir.

Analisis dilanjutkan dengan memperhatikan output pada classification table (Tabel 5.6), yang dapat diintepretasikan bahwa model prediksi yang digunakan diperkirakan mampu mencapai kebenaran prediksi yang mencapai $86.1 \%$. Dengan role of thump probabilitas 50\%-100\%, maka model prediksi dalam penelitian ini dapat dikatakan baik.

Hasil Output dari analisis probit-logit atas variabel dalam model penelitian ditampilkan dalam "Variables in the Equation" (tabel 5.7). didapat hasil bahwa, hanya tiga variabel yang memiliki signifikansi secara statistik $(<0.05)$. Variabel independen tersebut adalah variabel pengetahuan aliran kas (finlit1), variabel kompetensi entrepreneurial (entshp) dan variabel keyakinan mengambil resiko (confid). Dari ketiga variabel tersebut, kompetensi entrepreneurial (entshp) adalah yang memiliki tingkat signifikansi statistik yang paling tinggi. Diikuti berturut - turut oleh variabel keyakinan mengambil resiko (confid) dan variabel pengetahuan aliran kas (finlit1).

Hasil analisis terhadap output pada tabel diatas (kolom $\operatorname{Exp}(B))$, selanjutnya memberikan intepretasi bahwa seseorang dengan variabel kompetensi entrepreneurial (entshp) memiliki 3.7 kali kemungkinan (lebih mungkin dengan) untuk memilih menjadi pekerja mandiri. Demikian pula dua variabel independen lainnya, pengetahuan atas aliran kas juga dapat meningkatkan kemungkinan (4.17 kali), bahkan dengan 
memiliki keyakinan mengambil resiko, seseorang memiliki kemungkinan lebih tinggi (36.2 kali) untuk memutuskan menjadi pekerja mandiri.

Model prediksi pilihan karir juga melibatkan variabel independen status kemahasiswaan, bidang keilmuan yang ditempuh pada perguruan tinggi, sebaran gender dan sebaran daerah asal domisili responden, namun tidak satupun dari variabel demografi tersebut yang memiliki signifikansi statistik untuk dikatakan mempengaruhi keputusan karir untuk menjadi pekerja mandiri. Signifikansi stastistik juga tidak dapat ditemukan pada hasil uji variabel mengenai "pengetahuan jenis asset" (finlit2), "pengetahuan Asuransi" (finlit3), "pengetahuan jenis investasi" (finlit4), "pengetahuan transaksi keuangan" (finlit5), atau dapat dikakan bahwa keempat variabel yang mengambarkan literasi keuangan tersebut tidak mempengaruhi keputusan karir mandiri seseorang.

\section{PEMBAHASAN}

Dari hasil yang didapat terkait pertanyaan penelitian mengenai relasi antara literasi keuangan dan kecendrungan atas karir yang dipilih, dengan indikator keputusan karir mandiri (self-employment) digunakan untuk menjelaskan dan membuktikan kebenaran asumsi tersebut. Penelitian ini memodelkan prediksi pilihan karir mahasiswa dengan merelasikannya terhadap literasi keuangan yang dilakukan pada mahasiswa di Kota Pontianak.

Sebagai hasilnya, dapat dikatakan bahwa untuk responden pemuda dengan karakteristik mahasiswa dan alumni perguruan tinggi di kota pontianak, tidak mendasari keputusan karir mereka untuk menjadi pekerja mandiri (self-employment), atas pengetahuan keuangan yang dimiliki (literasi keuangan). Namun keputusan menjadi pekerja mandiri (self-employment) lebih mungkin diambil jika mereka mendapat/memiliki kompetensi kewirausahaan dan keyakinan diri yang tinggi.

Pilihan karir mandiri sangat umum diasosiasikan dengan menjadi seorang menjadikan seseorang entrepreneur. Karakteristik yang dituntut dari seorang yang memilih karir mandiri (self-employment) diantaranya adalah mampu bertanggung jawab secara langsung terhadap hasil, dimana keahlian dan kesungguhan pribadi sangat diutamakan serta sadar akan keberadaan resiko (Njoroge, 2012).

Hal itu tentu nya didasari atas sifat alamiah dari karir mandiri (self employment) yang akan selalu berhadapan dengan ketidakpastian. Sehingga sangat masuk akal jika keyakinan diri yang tinggi dalam pengambilan keputusan yang mengandung resiko (Risk Taking) sangat diperlukan dalam diri seorang entrepreneur. Resiko yang paling utama disebutkan adalah ketidakpastian laba (Venkataraman, dalam Njoroge, 2012), meskipun banyak pula aspek lain yang dicatatkan sebagai bentuk ketidak pastian yang akan dihadapi oleh seorang entrepreneur (Liles dalam Njoroge, 2012). Namun seorang dengan pilihan karir mandiri seperti menjadi entrepreneur juga dituntut untuk mampu menjalankan kegiatan entrepreneurial-nya secara ekonomis atau dengan kata lain adanya pertimbangan yang cukup terkait penggunaan sumberdaya dan hasil yang didapat yang mana ukuran pertimbangan ini secara umum adalah nilai uang.

Pertimbangan yang mengarah pada keputusan keuangan yang lebih baik cenderung ditemukan pada entrepreneur dengan literasi keuangan yang baik. Penelitian yang dilakukan oelh Bruhn dan Zia ditahun 2011 (fatoki, 2014) mendapatkan hasil bahwa entrepreneur dengan literasi keuangan mampu menunjukan kinerja usaha dan penjualan yang lebih baik. Sementara Andoh and Nunoo (dalam fatoki, 2014) 
mengungkapkan pemilik usaha dengan literasi keuangan yang cukup lebih mampu memanfaatkan jasa lembaga keuangan. Sehingga sangatlah dikhawatirkan, absennya literasi keuangan dalam pertimbangan memutuskan karir mandiri (selfemployment) dapat berujung pada kinerja karir (usaha) yang buruk atau bahkan mengalami kegagalan.

Absennya mayoritas dari variabel yang merepresentasikan literasi keuangan menjadikan mereka cenderung rentan untuk mengambil keputusan keuangan yang beresiko tinggi. Keputusan keuangan yang beresiko dan dianggap dapat menjadi sebab dalam kegagalan para pekerja mandiri khususnya wirausahawan diantaranya adalah penetapan harga layanan/ produk yang emosional, pinjaman (kredit) yang melebihi kemampuan, tidak melakukan pencatatan keuangan, aktifitas usaha tanpa penganggaran, bahkan membentuk image pribadi/usaha yang melebihi kemampuan (Jones (2009); Berglund (2007) dalam Kaminskaite, 2017).

\section{SIMPULAN}

Penelitian ini mengungkap keberadaan relasi literasi keuangan dengan pilihan karir mahasiswa pada Perguruan Tinggi di Kota Pontianak melalui pemodelan prediksi matematika dengan melibatkan variabel yang diduga berelasi dengan keputusan pilihan karir mahasiswa, yang hasilnya secara berturut-turut terindentifikasi, sebagai berikut:

1. Hasil Output model penelitian menggunakan analisis probit-logit atas variabel yang dilibatkan mendapati bahwa, hanya tiga variabel yang memiliki signifikansi secara statistik $(<0.05)$. Variabel independen tersebut adalah variabel pengetahuan aliran kas (finlit1), variabel kompetensi entrepreneurial (entshp) dan variabel keyakinan mengambil resiko (confid).

2. variabel independen status kemahasiswaan, bidang keilmuan yang ditempuh pada perguruan tinggi, sebaran gender dan sebaran daerah asal domisili responden yang merupakan variabel demografi, tidak satupun memiliki signifikansi statistik untuk dikatakan mempengaruhi keputusan karir untuk menjadi pekerja mandiri.

3. Signifikansi stastistik tidak dapat ditemukan pada hasil uji variabel independen "pengetahuan jenis asset" (finlit2), "pengetahuan Asuransi" (finlit3), "pengetahuan jenis investasi" (finlit4), "pengetahuan transaksi keuangan" (finlit5), atau dapat dikatakan bahwa keempat variabel yang mengambarkan literasi keuangan tersebut tidak mempengaruhi keputusan karir mandiri dari responden yang mewakili mahasiswa.

\section{REFERENSI}

Avlijaš,Goran., Avlijaš, Radoslav, Heleta, Milenko (2014), Financial Literacy As a Factor in Reducing Entrepreneurial Risk, Singidunum University International Scienti_c Conference, diakses 2017 tersedia http://portal.finiz.singidunum.ac.rs/M edia/files/2014/112-114.pdf

Baraghani, Sara Naimi (2007) Factor Influencing The Adoption of Internet Banking.

Cumurovi'c, Aida and Hylly, Walter (2017), Financial Literacy and SelfEmployment, Halle Institute for Economic Research, Kleine Maerkerstrasse 8, 06108 Halle, Germany diakses pada februari 2018. 
tersedia http://gflec.org/wpcontent/uploads/2017/04/CUMURO VIC-Paper-Cherry Blossom2017.pdf?x87657

Fatoki, Olawale (2014) The Financial Literacy of Micro Entrepreneurs in South Africa, University of Limpopo, South Africa.

Istiariani, I. (2020). Ethic and the affecting factors: Insights from sharia accounting students. Journal of Islamic Accounting and Finance Research, 2(1), 1. https://doi.org/10.21580/jiafr.2020.2. 1.5037

Krechovská, Michaela (2015), Financial Literacy as a Path to Sustainability, Uwb , Pilsen diakses 2017 tersedia https://www.dfek.zcu.cz/tvp/doc/akt/ 2-2015-clanek-1.pdf

Mohan, A. Chandra., Prasad, B V S, (2011) Emotional Intelligence and Self Motivational Factors For Managerial Effectiveness in The Corporate
World, diakses 2012 tersedia di: www.abhinavjournal.com

Neuman, W. Lawrence (2006), Social Research methods: Qualitative And Quantitative Approaches 6th Edition, Pearson Education, Inc, United States of America.

Njoroge M. Robert (2012), Relationship Between Financial Literacy And Entrepreneurial Success In Nairobi County Kenya, University of Nairobi, diakses 2017 tersedia http://chss.uonbi.ac.ke/sites/default/file s/chss/NJOROGE\%20ROBERT-D6175875-2012.pdf

WEF (2016), Global Competitiveness Report 2015-2016 , diakses 2017 tersedia http://reports.weforum.org/globalcompetitiveness-report-20152016/competitiveness-rankings/

Yuan, Haowen, "How Financial Literacy Affects Budgeting Behaviors" (2015). Student Scholarship - School of Business, George Fox University, diakses $2018 \quad$ tersedia http://digitalcommons.georgefox.edu /gfsb_student/4 